\title{
The Development of an Innovative and Interactive Practical Guide for Senior High School, Integrated Discovery Learning in The Subject Matter of Chemical Elements.
}

\author{
Fitri Anggraini", Ramlan Silaban*, Iis Siti Jahro* \\ \# STIKOM Tunas Bangsa and Chemical Education Graduate Programs, State University of Medan, 20221, Indonesia \\ E-mail: fitrianggraini@stikomtb.ac.id
}

*Department of Chemistry, State University of Medan, Williem Iskandar Street Psr. V, Medan, 20221, Indonesia

\begin{abstract}
This research aims to develop an innovative and interactive practical guide for senior high school, integrated discovery learning in the subject matter of chemical elements in class XII corresponding semester of education unit level curriculum (KTSP). This kind of research is $R \& D$ (research and development) and experiments. $R \& D$ is the research that used to result in specific product and test the effectiveness of the product. Practical guidance available and practical guidance has been developed, validated by 2 respondents chemistry lecturer and 25 respondents high school chemistry teacher. Practical guidance available obtain an average value of 4.00 for the validation of lecturers, and 3.80 for the validation chemistry teacher. Practical guidance that has been developed obtain an average value of 4.0 for the validation of lecturers, and 3.88 for the validation chemistry teacher. Practical guidance that has been developed and then tested on a limited basis in Tanah Jawa high school, then divided into two groups. The first group uses practical guidance available, and the second group using practical guide has been developed. Based on the result of limited testing, obtained by improving student learning outcomes by $39 \%$ with a significance level of $<0.05$. THE DEVELPOMENT OF AN INNOVATIVE AND INTERACTIVE PRACTICAL GUIDE FOR SENIOR HIGH SCHOOL, INTEGRATED DISCOVERY LEARNING IN THE SUBJECT MATTER OF CHEMICAL ELEMENTS.
\end{abstract}

Keywords - Practical Guide, Research and Development, Discovery Learning.

\section{INTRODUCTION}

Studied chemistry not only to master the body of knowledge in the form of facts, concepts or principles, but the chemistry is an experimental science that can be learned only through reading, writing, or listening [7]. In line with this, reference [2] stating parable of chemistry learning, that a man who learned to draw, but without using paint and canvas, or someone trying to learn cycling, but without the use of bicycles, as well as someone who studied chemistry without doing practical work. This means that the most effective learning chemistry can be done through practical activities.

In general there are three scientific approaches that can be done by educators to meet the needs of diverse learners, especially those in the study of chemistry, namely: discovery learning, projectbased learning, and problem-based learning. In general, the approach is an attempt educator to improve the motivation and interest of learners to chemistry in efforts to improve learning achievement [3].

Discovery learning is a teaching model that emphasizes the importance of helping students understand the structure of the key ideas or discipline, the need for active involvement of students in the learning process, and the belief that true learning occurs through personal discovery. Practical guide developed innovative and interactive can be used in learning chemistry. This interactive guide innovative practicum can be done by utilizing what is there at the moment, for example, on the environment and teacher interaction, the use of computer software, such as Microsoft PowerPoint, Macromedia Flash, Cool Audition, Photoshop, Movie Maker, and others. Reference [8] states, learning innovation to improve student achievement in chemistry learning is needed because it deals directly with improving the quality of graduate to fill jobs in chemistry.

In the laboratory, the involvement of teachers can develop physical and mental, and emotional learners. Learners have the opportunity to practice the skills of the process in order to obtain maximum learning results. Experience that is directly embedded longer in his mind, as opposed to just hearing recounted the experience of others. Involvement of physical, mental and emotional learners are expected to lead to the learning conditions that can increase confidence and also innovative and creative behaviour. By experimenting, students are invited to become a chemist. With so they can understand their own processes and chemical concepts according to the results obtained during the study. 
Based on the above problems, the researchers want to develop high school lab by integrating discovery learning into the practical guide. In general, this study aims to:

- Analysing practical guide used to use the contents of eligibility questionnaire.

- Produce practical handbook which has been developed that meet the standard BSNP.

- Produce practical handbook which has been developed that meets the eligibility to use in learning.

- Knowing the effectiveness and efficiency of practical handbook has been developed to increase student learning outcomes.

\section{RESEARCH METHODOLOGY}

Research has been conducted in Simalungun, North Sumatra. Selection of research sites is limited, through consideration of locations that can be reached by author. The research was conducted for November 2015 to February 2016. The study sample was taken by purposive sampling. Sample a class XII student of SMA Negeri 1 Tanah Jawa who has studied chemical material elements. Samples were divided into two groups; group 1 using existing practical handbook and group 2 using practical handbook has been developed. The number of samples taken from each group is 16 people.

This type of research is R\&D (research and development) and experiment. Learning outcomes of the use of practical guides that have been developed, measured at the end of the study. Implementation research to obtain research data consisted of:

- Analysing the practical guide available.

- Develop of an innovative and interactive practical guide according to the syntax Discovery Learning.

- Standardization of practical guide according to national educations standards.

- Test the feasibility of practical guide by the validation expert (Lecturers and Teachers).

- Limited testing of practical guide in SMA Negeri 1 Tanah Jawa.

- Limited testing results of practical guide in SMA Negeri 1 Tanah Jawa.

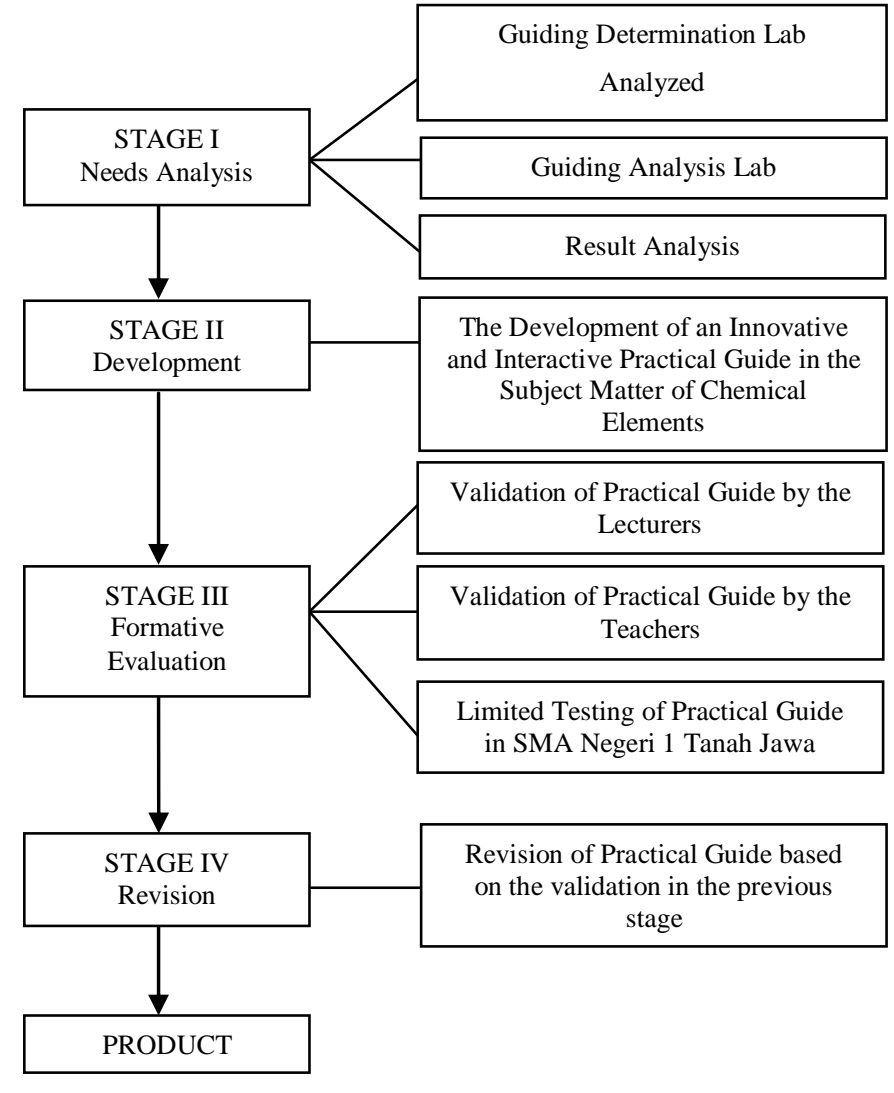

Fig. 1 Chart a research procedure

With about the same item, the pre-test and posttest one group did a test with questions presented on sheets of paper matter, while the second group did a test questions presented in the media exelearning.

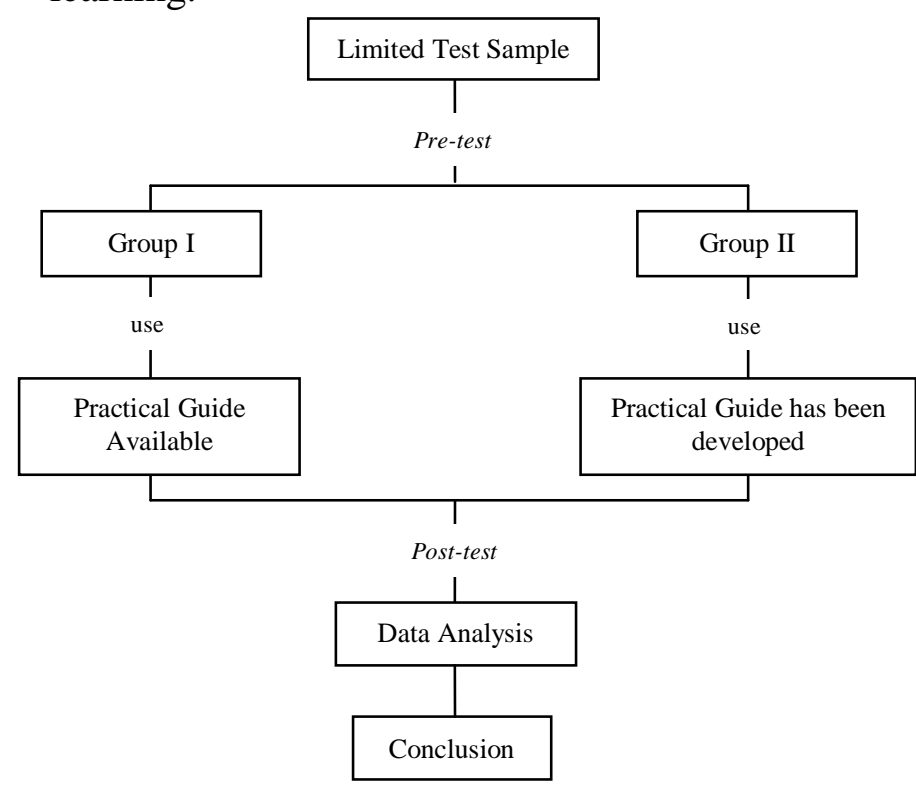

Fig. 2 Limited testing procedure

The technique used to collect data in this study is the testing techniques, data collected obtained from the study in the form of the result of the pre- 
test and post-test data analysis technique that is used to test the hypothesis, before testing the hypothesis done first test preconditions, namely: (1) normality; (2) homogeneity; and (3) the data form the questionnaire.

\section{RESULT AND DISCUSSION}

One of the outstanding practical guidance is practical guide of the issuer in accordance Pudak Scientific education unit level curriculum (KTSP).This book contains the analysis of the curriculum, matriculation, the introduction of tools and materials, laboratory techniques and preparation of the solution. The book presents a practical experiment that can be performed for high school chemistry class XII for the first semester and second semester.

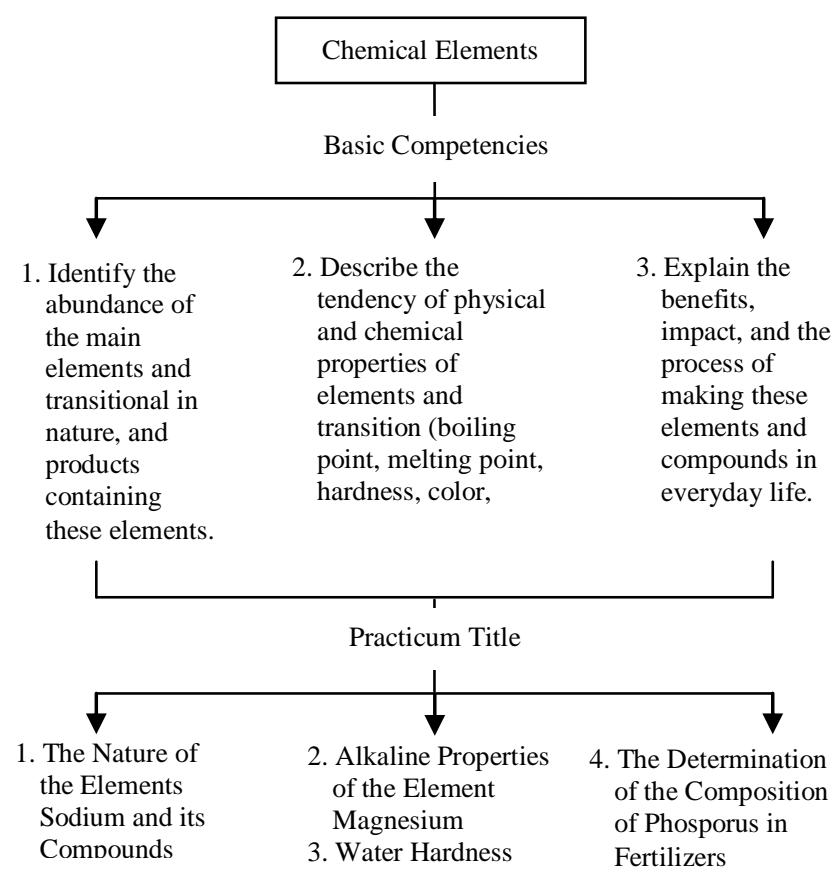

Fig. 3 Subject matter developed

The results of analysis the average value of the distribution of questionnaires lecturer of 4.04 and an average value for the distribution of teacher questionnaire 3.80. Having analyse and know the other components of outstanding practical guidance, in this handbook, we conducted the development of practical guidance with chemical material elements. The development of practical guidance is tailored to the educational unit level curriculum (KTSP) that is integrated with the innovative and interactive discovery learning.
This development is adapted to the basic competence (KD) and indicators in accordance with the syllabus, as shown in Fig. 3. Guidance lab developed. This is a practical guide that is innovative and interactive, in which available compact disc learning. Where in the learning $\quad \mathrm{CD} \quad$ contained exe-learning application that explains some of the benefits of the elements on human life and in this application there is also a matter of interactive exercises chemical material elements.

Guidance chemistry lab chemical materials elements of an innovative and interactive integrated discovery learning that has been conceived and developed appropriate level curriculum for education (KTSP) is then standardized by the validity test using a questionnaire by respondents consisted of 2 chemistry professor, State University of Medan and 25 chemistry teacher High School. The results of the analytical chemistry lab guides that have been validated by lecturers and teachers are as follows:

\section{A. Practical Guidance Validation Results for Lecturers}

Respondents were selected lecturers are 2 chemistry professor at the State University of Medan with educational background S3 (PhD) and has had a long teaching experience. Questionnaires were given to respondent lecturer standard assessment questionnaire guiding chemistry lab according BSNP to assess some aspects of feasibility, among other aspects of the feasibility of content, appropriateness of language, presentation feasibility, and graph feasibility. The results can be seen in the diagram in Fig. 4.

Based on the validation results of the feasibility test lab guides integrated discovery learning by two lecturers obtained that the practical guidance is feasible and does not need to be revised. For eligibility contents, the average value obtained at 4.04 , on the feasibility of the language gained an average of 4.1 , for the presentation of the feasibility gained an average of 3.79 , and for graph feasibility obtained an average yield of 4 06. In the questionnaire, the respondents added some suggestions in the form of additional practical illustration of pictures and the addition of a reference library. 


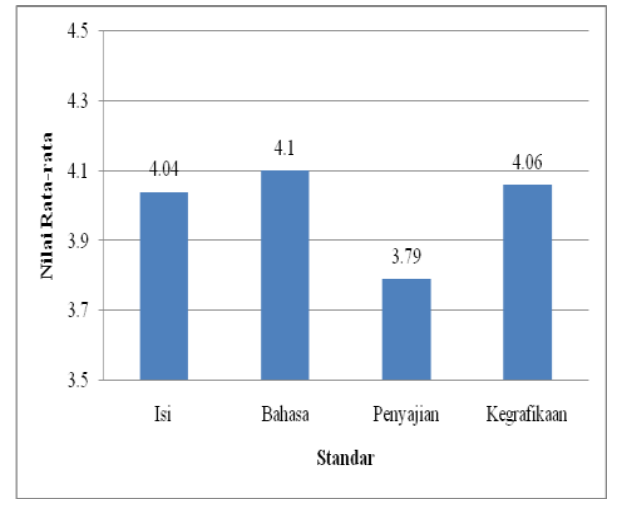

Fig. 4 The results validate the feasibility test lab guides that have been developed in accordance with national education standards

\section{B. Practical Guidance Validation Results for High School Teachers}

Respondents who have involved 25 high school chemistry teacher with an educational background of at least S1. The instrument used was a questionnaire which has been standardized and has been used by previous researchers associated with the standardization feasibility of guiding practical. The results of the validation by the respondent teachers are as follows:

1) Coverage Practical Aspects: In the practical aspect of coverage, there are four components related thereto, among others; (a) the breadth of the lab; (b) suitability practicum with SK and $\mathrm{KD}$; (c) conformity with the practical purpose of learning indicators; and (d) procedures used lab model applied learning. Of the four components obtained average value sequentially by $3.6 ; 3.96 ; 3.76$; and 3.96 with an average overall score of 3.82 , which means it has a decent guide and does not need to be revised. The test results for the feasibility of practical aspects of coverage can be seen in the diagram contained in Fig. 5.

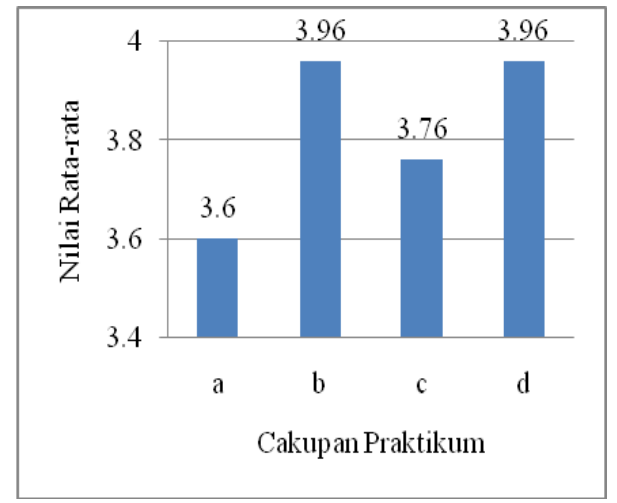

Fig. 5 The results validate the feasibility test lab guides that have been developed based on practical coverage

2) Systematics aspects Presentation: In a systematic presentation aspect, there are three components associated therewith, among others; (a) arrangement of the presentation; (b) the identity of tables, images, and attachments; and (c) the practical procedure is described in a systematic and clear. Of the three components of the average values obtained sequentially at $4.08 ; 3.68$; and 4 with an average overall score of 3.92 , which means it has a decent guide and does not need to be revised. The test results for the feasibility of a systematic aspect of the presentation can be seen in the diagram contained in Fig. 6.

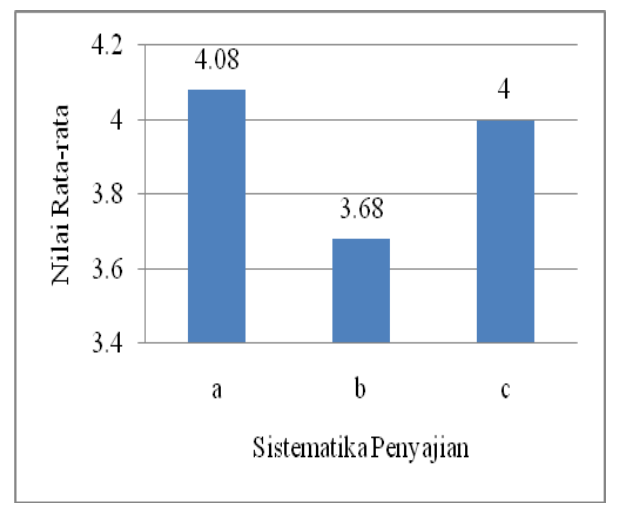

Fig. 6 The results validate the feasibility test lab guides that have been developed based on a systematic presentation

3) Contains aspect Productivity Insights: A In the aspect of it contains insights productivity, there are two components associated therewith, among others; (a) foster the work ethic of students; and (b) foster a spirit of innovation, creative and critical thinking in students. The second component of the average values obtained sequentially by 4.04 and 3.96 with an average overall score of 4 , which means it has a decent guide and does not need to be revised. The test results contain insights eligibility to aspects of productivity can be seen in the diagram in Fig. 7.

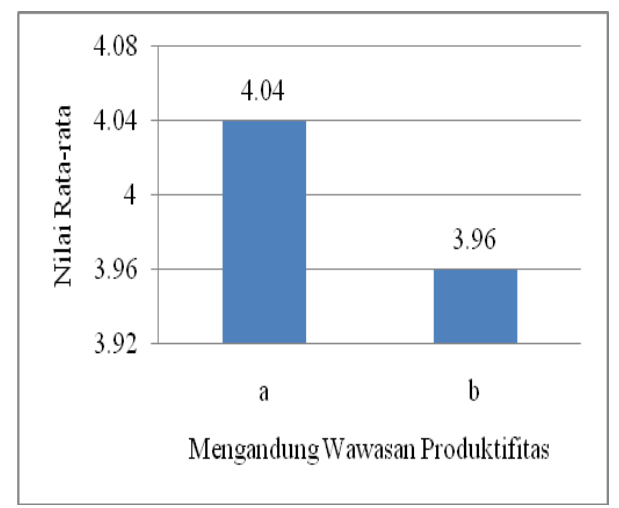

Fig. 7 The results validate the feasibility test lab guides that have been developed by containing insights productivity

4) Aspects Stimulating Curiosity: In the aspect of stimulating curiosity, there are two components associated therewith, among others; (a) raising the curiosity of students; and (b) provide a challenge for even further. The second component of the average values obtained sequentially by 3.92 and 4.08 with an average overall score of 4 , which means it has a decent guide and does not need to be revised. The results of due diligence to stimulate the curiosity aspect can be seen in the diagram contained in Fig. 8. 


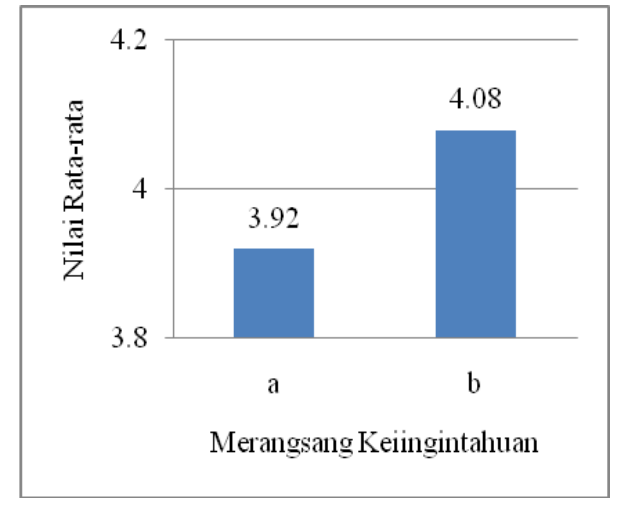

Fig. 8 The results of the validation test of the feasibility of a guide that has been developed by stimulating curiosity

5) Aspects of Developing Life Skills: In the aspect of developing life skills (life skills), there are three components associated therewith, among others; (a) develop personal skills; (b) develop psychomotor abilities of students; and (c) developing academic skills. Of the three components of the average values obtained sequentially by $3.96 ; 3.88$; and 3.8 with an average overall score of 3.88 , which means it has a decent guide and does not need to be revised. The test results eligibility to aspects of developing life skills (life skills) can be seen in the diagram contained in Fig. 9.

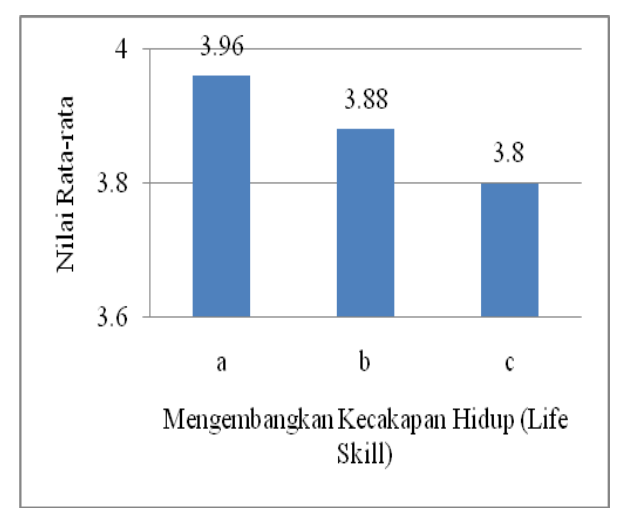

Fig. 9 The results validate the feasibility test lab guides that have been developed by developing life skills

6) Design aspects: In the aspect of design, there are two components associated therewith, among others; (a) the presentation of images, tables and symbols; and (b) interactive. The second component of the average values obtained sequentially by 3.6 and 3.68 with an overall average score of 3.64 , which means it has a decent guide and does not need to be revised. The results of the feasibility test for the design aspect can be seen in the diagram contained in Fig. 10.

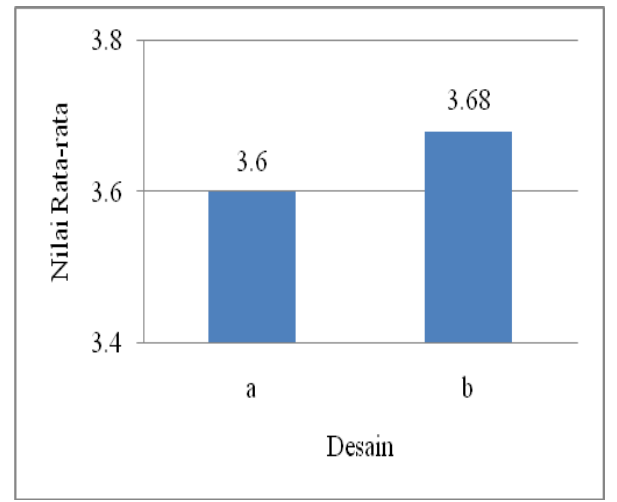

Fig. 10 The results validate the feasibility test lab guides that have been developed based on the design

7) Aspects Of Language: In the aspect of the language, there are three components associated therewith, among others; (a) in accordance with the development of learners;(b) communicative; and (c) the consistency of the use of terms and symbols on the practical guide. Of the three components of the average values obtained sequentially by 3.96 ; 3.96 ; and 3.84 with an average overall score of 3.92 , which means it has a decent guide and does not need to be revised. The test results eligibility to aspects of language can be seen in the diagram in Fig. 11.

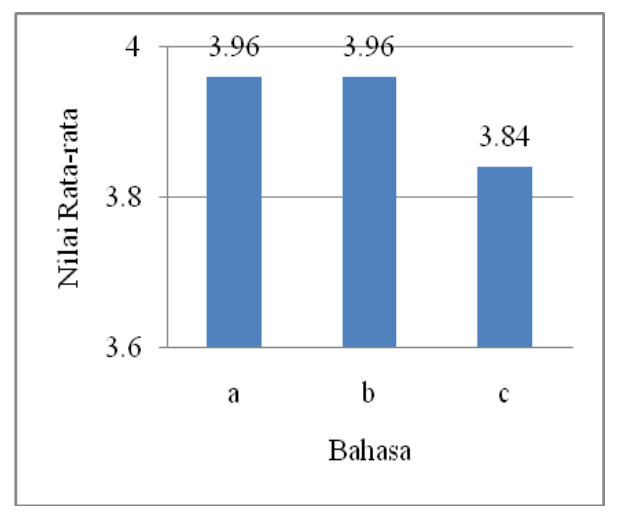

Fig. 11 The results validate the feasibility test lab guides that have been developed by language

To find out the increase learning outcomes by learning using practical guidance that has been developed involves two groups of students, with each group of 16 people. Group 1 study using lab guides that circulate (control group) and group 2 using a practical guide that has been developed (experimental group).

In each group performed first test early (pretest) which aims to determine students' prior knowledge, and after being given treatment and then the students are given a final test (posttest). Where in group 1, test questions are presented in the form of plain paper and for the second group test questions presented interactively in the form of exe-learning. 
Obtaining the average value of pre test in group 1 and group 2 is 55 scored an average of 43. As for the post-test in group 1 gained an average value of 75 and a group 2 gained an average value of 82. Based on the results pre-test and post-test of students, there are differences in the average value that is necessary to determine the value of the gain is normalized results of studying chemistry in the group.

Earned value normalized gain in group 1 and group 2 respectively are 0.19 and 0.3 . It can be concluded that the average value of normalized gain was lowest in group 1, the group using practical handbook circulated, while in group 2 , which uses practical guidance that has been developed obtain the average normalized gain higher.

Guidance lab validated then repaired. Repair to practical guidance is based on suggestions and feedback that has been given by the respondent. Suggestions of additional illustrations and a reference library were added later for the final product of an innovative and interactive practical guide, integrated discovery learning in the subject matter of chemical elements in grade XII senior high school.

\section{CONCLUSIONS}

Based on data analysis and discussion, it can be concluded that:
- Practical guidance provided meets the standards BSNP.

- Practical guidance that has been developed in compliance with the standards BSNP.

- Practical guidance that has been developed in compliance with the eligibility for use in learning, and does not need to be revised.

- Practical guidance that has been developed effectively and efficiently to improving student learning outcomes in the subject matter of chemical elements.

\section{REFERENCES}

[1] BSNP, Panduan Penyusunan Bahan Ajar, Depdiknas, Jakarta, 2006.

[2] Tezcam, H., and Bilgin, E., "Affects of Laboratory Method and Other Factors on The Students Success in The Teaching of The Vation Subject at The High School", The Journal of Gazi Educational Faculty, vol 24, pp. 175-191, 2004.

[3] Zakiah, "Pengembangan Penuntun Praktikum Tipe Discovery dan Project Based Learning pada Pembelajaran Larutan Elektrolit dan Nonelektrolit di SMA", Jurnal Pendidikan Kimia, vol 07, pp. 70-79, 2015.

[4] Jaya, H., "Pengembangan Laboratorium Virtual untuk Kegiatan Praktikum dan Memfasilitasi Pendidikan Karakter di SMK”, Jurnal Pendidikan Vokasi, vol 02, pp. 81-90, 2012.

[5] Situmorang, H., and Situmorang, M., "Keefektifan Media Komputer dalam Meningkatkan Penguasaan Kimia Siswa Menengah Atas Kejuruan pada Pengajaran Materi dan Perubahannya", Jurnal Pendidikan Matematika dan Sains, vol 3, pp. 45-51, 2009.

[6] Johari, J.M.C., and Rachmawati, M., Chemistry for Senior High School Grade XII, Esis, Jakarta, 2012.

[7] Jahro, I.S., "Analisis Penerapan Metode Praktikum pada Pembelajaran Ilmu Kimia di Sekolah Menengah Atas", Jurnal Pendidikan Kimia, vol 01, pp. 20-26, 2009.

[8] Machtmes, K., Johnson, E., Fox, J., and Burke, M.S., "Teaching Qualitative Research Methods Through Service Learning", The Qualitative Report, vol 04, pp. 155-165, 2009.

[9] Tim Pudak Scientific, Kimia, Pudak Scientific, Bandung, 2008.

[10] Tuysuz, C., "The Effect of The Virtual Laboratory on Students Achievement and Attitude in Chemistry", IOJES, vol 02, pp. 37-53, 2010 . 